\title{
An extremely rare gastric lesion: gastritis cystica profunda
}

\section{Oldukça nadir bir gastrik lezyon: gastritis cystica profunda}

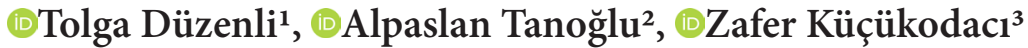 \\ ${ }^{1}$ Sultan Abdulhamid Han Training and Research Hospital, Department of Gastroenterology, Istanbul, Turkey \\ ${ }^{2}$ Hitit University Erol Olcok Training and Research Hospital, Department of Gastroenterology, Corum, Turkey \\ ${ }^{3}$ Sultan Abdulhamid Han Training and Research Hospital, Department of Pathology, Istanbul, Turkey
}

Cite this article as/Bu makaleye atıf için: Düzenli T, Tanoğlu A, Küçükodacı Z. An extremely rare gastric lesion: gastritis cystica profunda. J Health Sci Med 2020; 3(4): 493-495.

\begin{abstract}
Gastritis cystica profunda (GCP) is an uncommon, benign lesion which looking a cancer-like lesion. This lesion is localized in gastric mucosa and characterized by polypoid hyperplasia or ulcerated mucosal lesion and cystic dilatation of the mucosal glands spreading into the submucosa of the stomach. Exact etiology and pathogenesis of GCP is still incompletely explained. In this case report we present a case of 70-year-old female with proton pump inhibitor resistant upper gastrointestinal symptoms who was diagnosed as GCP after upper gastrointestinal system endoscopy examination. This rare benign entity should be kept in mind in the differential diagnosis of gastric mural mass lesions.
\end{abstract}

Keywords: Gastric lesion, endoscopy, cancer, gastritis cystica profunda

\section{ÖZ}

Gastritis cystica profunda (GCP), kansere benzer bir görünüme sahip nadir, iyi huylu bir lezyondur. Bu lezyon mide mukozasında lokalizedir ve polipoid hiperplazi veya ülsere mukozal lezyon ve midenin submukozasına yayılan mukozal bezlerin kistik dilatasyonu ile karakterizedir. GCP’nin kesin etiyolojisi ve patogenezi hala tam olarak açıklanamamıştır. Bu olgu sunumunda, üst gastrointestinal sistem endoskopi incelemesi sonrası GCP tanısı alan, proton pompa inhibitörüne dirençli üst gastrointestinal semptomları olan 70 yaşında bir kadın olguyu sunuyoruz. Nadir görülen bu benign antite, gastrik mural kitle lezyonlarının ayırıcı tanısında akılda tutulmalıdır.

Anahtar kelimeler: Gastrik lezyon, endoskopi, kanser, gastritis cystica profunda

\section{INTRODUCTION}

Gastritis cystica profunda (GCP) is an uncommon, benign gastric submucosal pathology characterized by polypoid hyperplasia and cystic dilatation of the gastric glands spreading into the submucosa of the stomach. Accurate diagnosis of this lesion can be confused with some other common stomach diseases $(1,2)$. Silent clinical symptoms and nonspesific endoscopic and radiographic appearance of this tumor mimic that of other hyperproliferative conditions making diagnosis difficult (3). Herein we report a very rare case of gastritis cystica profunda which we had presumed as a gastric cancer and emphasize the differential diagnosis of this rare entity.

\section{CASE REPORT}

A 70-year-old woman was referred to our outpatient clinic with the complaints of abdominal fullness, heartburn, nausea and belching regardless of proton pump inhibitor drugs (PPIs) for the last three months. She had only a past history of hypertension however she had never used tobacco or alcohol. Her family history was negative for gastric pathologies including gastric cancer. Her detailed physical examination revealed no pathological findings. Whole blood, routine blood and stool blood test showed no abnormalities. Because of ongoing dyspeptic symptoms she underwent upper gastrointestinal endoscopy. During upper gastrointestinal system endoscopy, it was noticed that there were nodular lesion at greater curvature of the antrum with an irregular 
depressed centre and a slightly elevated margin and focal flat elevated lesion at anterior wall of the corpus. The lesion had an intriguing appearance and also, she had PPIs resistant dyspepsia. Thus, our prediagnosis was as an early gastric cancer. Multiple biopsies were obtained by the senior endoscopist and no mucosal hemorrhage was occured. Pathological findings were polypoid cystic ectasia of the submucosal layer with cystic dilatation of the glandular structures without mitoses or atypia (Figure). Finally, 'gastritis cystica profunda'was the pathological diagnosis. She was not undergoing a surgical operation, and outpatient follow up is ongoing with PPI use.

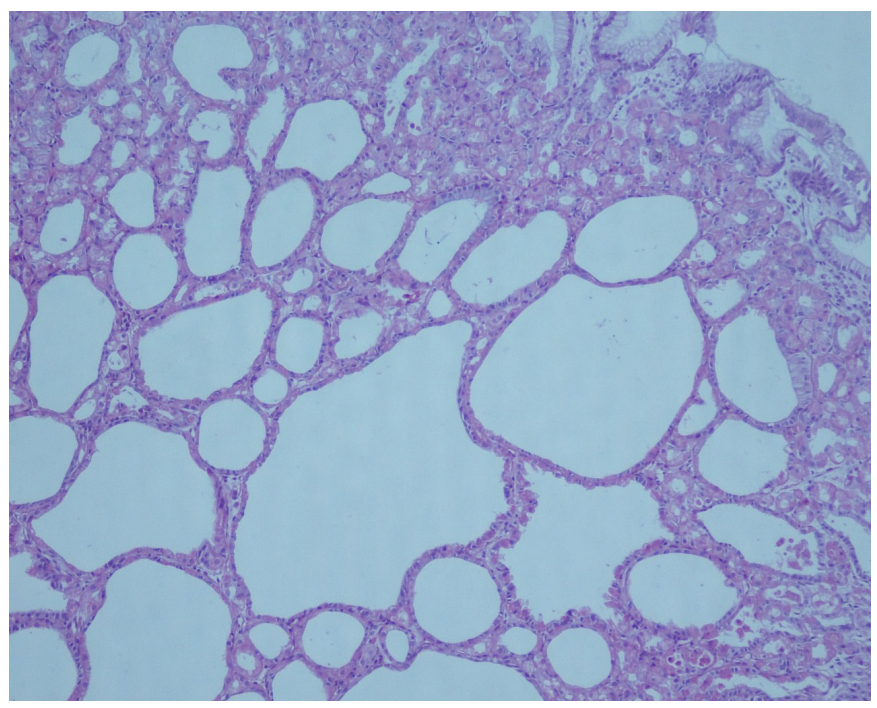

Figure. Polypoid cystic ectasia of the submucosal layer with cystic dilatation of the glandular structures without mitoses or atypia, HEx100.

\section{DISCUSSION}

In this rare gastric case report, we have exhibited the dilemma in exact diagnosing a lesion with upper gastrointestinal system endoscopic visuality of an 'early gastric cancer'but which was completely histologically benign. Usually, in case of this cancer mimicking benign lesion, a number of gastroscopies and radiological interventions are needed to be confident of an accurate diagnosis $(2,3)$.

GCP is a rare gastric pathology characterized by the presence of gastric glands in the submucosa of the stomach with normal overlying mucosa and is often mistaken for other more common gastric problems (4). Clinical manifestations and symptoms of GCP are typically nonspecific, leading to significant diagnostic uncertainty. Histological examination of biopsy specimen is nearly non-diagnostic and a formal surgical excision is generally required $(5,6)$.
A globally accepted treatment strategy for GCP has not been well described given the uncommon manner of these gastric lesions and the exact difficulty of diagnosing them (7). GCP is generally benign, although there have been some reports of GCP associated with cancer, but this hypothesis remains difficult to prove $(8,9)$. Moon et al. reported two cases of GCP accompanied by synchronous multiple early gastric cancers occurred in patients without previous gastric surgery (4). In a pathological study of Choi et al. examining 10728 patients with gastric cancer, it was found in 161 patients (10). There are some case reports of GCP coexisting with Ménétrier disease or gastric inverted hyperplastic polyps $(11,12)$.

The natural course of GCP is ambiguous and needs more molecular and histopathological exploration. This rare entity should be kept in mind in the differential diagnosis of patients presenting with suspicious submucosal gastric lesions.

\section{ETHICAL DECLARATIONS}

Informed Consent: Written informed consent was obtained from all participants who participated in this study.

Referee Evaluation Process: Externally peerreviewed.

Conflict of Interest Statement: The authors have no conflicts of interest to declare.

Financial Disclosure: The authors declared that this study has received no financial support.

Author Contributions: All of the authors declare that they have all participated in the design, execution, and analysis of the paper, and that they have approved the final version.

\section{REFERENCES}

1. Littler ER, Gleibermann E. Gastritis cystica polyposa. (Gastric mucosal prolapse at gastroenterostomy site, with cystic and infiltrative epithelial hyperplasia) Cancer 1972; 29: 205-9.

2. Franzin G, Novelli P. Gastritis cystica profunda. Histopathology 1981; 5: 535-47.

3. Butt MO, Luck NH, Hassan SM, Abbas Z, Mubarak M. Gastritis profunda cystica presenting as gastric outlet obstruction and mimicking cancer: A case report. J Transl Int Med 2015; 3: 35-7.

4. Moon SY, Kim KO, Park SH, et al. Gastritis cystica profunda accompanied by multiple early gastric cancers. Korean J Gastroenterol 2010; 55: 325-30.

5. Ozenc AM, Ruacan S, Aran O. Gastritis cystica polyposa. Arch Surg. 1988; 123: 372-3.

6. Tuncer K, Alkanat M, Musoglu A, Aydin A. Gastritis cystica polyposa found in an unoperated stomach: An unusual case treated by endoscopic polypectomy. Endoscopy 2003; 35: 882 . 
7. Park JS, Myung SJ, Jung HY, et al. Endoscopic treatment of gastritis cystica polyposa found in an un-operated stomach. Gastrointest Endosc 2001; 54: 101-3.

8. Park CH, Park JM, Jung CK, et al. Early gastric cancer associated with gastritis cystica polyposa in the unoperated stomach treated by endoscopic submucosal dissection. Gastrointest Endosc 2009; 69: e47-50.

9. Aoyagi K, Koufuji K, Yano S, et al. Two cases of cancer in the remnant stomach derived from gastritis cystica polyposa. Kurume Med J 2000; 47: 243-8.

10. Choi MG, Jeong JY, Kim KM, et al. Clinical significance of gastritis cystica profunda and its association with Epstein-Barr virus in gastric cancer. Cancer 2012; 118: 5227-33.

11. Soares JB, Bastos P, Goncalves R. Menetrier disease with antrum polyposis and gastritis cystica profunda. Endoscopy 2012; 44: E56-7.

12. Yamashita M, Hirokawa M, Nakasono M, et al. Gastric inverted hyperplastic polyp report of four cases and relation to gastritis cystica profunda. APMIS 2002; 110: 717-23. 